\title{
Factors Affecting Satisfaction of Customers' Savings Deposit in the Context of COVID-19: Evidence from Vietnamese Commercial Banks
}

\author{
Quoc Thinh TRAN', Mai Uoc TRAN², Xuan Thuy LE ${ }^{3}$ \\ Received: July 25, 2020 Revised: August 23, 2020 Accepted: September 03, 2020
}

\begin{abstract}
Credit capital from customers' savings deposit (CSD) of banks has an important meaning in the business activities of the banking industry. There are many factors that influence the CSD satisfaction with banks. Certain changes have been made when there are fluctuations due to COVID-19. The article is based on an analysis assessing the factors that influence the CSD satisfaction of Vietnamese commercial banks in the context of COVID-19. The authors use a sample of 1,639 CSD. The results show that there are three variables that positively affect CSD satisfaction, including legal provisions of the Central bank (Legal), policies and mechanisms of commercial banks (Policy), and products of commercial banks (Product). Accordingly, in order to contribute to strengthening this capital mobilization of savings deposit, the Central bank of Vietnam needs to play a pivotal role in the regulations of the banking system to ensure its stability; control well monetary policy, interest rates, and inflation to keep a stable position in the economy; and provide timely financial support packages to enhance the confidence of CSD. Moreover, Vietnamese commercial banks need flexible policies and mechanisms to stimulate CSD; strengthen support on deposit rates for CSD; and diversify products to easily adapt to each CSD's situation.
\end{abstract}

Keywords: Customer Satisfaction, Commercial Bank, COVID-19, Credit Mobilization, Savings Deposit, Vietnam

JEL Classification Code: G21, E51, H81

\section{Introduction}

In the trend of development and integration, capital resources play an important role to promote economic growth of countries. Accordingly, attracting this capital source, namely, savings deposit, is an essential issue that is of great interest to international organizations, countries and researchers. Attracting internal capital from customers' savings deposit (CSD) to take advantage and exploit the promoted economic development of the countries (Miklós et al, 2019). A number of studies focuses on finding discovery

${ }^{1}$ First Author and Corresponding Author. Associate Professor, Faculty of Accounting and Auditing, Industrial University of Ho Chi Minh City, Vietnam [Postal Address: 86 Nguyen Hong Street, Ward 1, Go Vap District, Ho Chi Minh City, 70000, Vietnam] Email: tranthinhktkt@gmail.com

${ }^{2}$ Associate Professor, Faculty of Political Economy, Banking University of Ho Chi Minh City, Vietnam. Email: pgstranmaiuoc@gmail.com

3Deputy Director, HD Bank, Vietnam. Email: tslexuanthuy@gmail.com

(c) Copyright: The Author(s)

This is an Open Access article distributed under the terms of the Creative Commons Attribution Non-Commercial License (https://creativecommons.org/licenses/by-nc/4.0/) which permits unrestricted non-commercial use, distribution, and reproduction in any medium, provided the original work is properly cited. factors related to typical CSD capital sources (Byusa, 2016; Far \& Zadeh, 2016; Gunasekara \& Kumari, 2018; Maxwell et al., 2018; Miklós et al., 2019; Tabash et al., 2020). To meet the trend of development and integration, Vietnam has made certain progress in mobilizing capital resources, in general, and mobilizing capital from CSD, in particular, for economic development in recent years. Up to now, it has mobilized capital, in which CSD has contributed to meet certain needs of national economic development (Nguyen, 2020; Vuong et al., 2020). However, the competitive trend for mobilizing resources for economic development is always a challenging issue and deserves attention, especially in the current situation of COVID-19.

COVID-19 has been occurring in Vietnam since the beginning of the first quarter of 2020 and has lasted until now. The regulations of the Central bank of Vietnam were issued to control the financial situation, monetary policy, interest rates, etc. (Central bank of Vietnam, 2020). This has occasioned a comprehensive change and affected CSD over time. To continue to attract CSD, the assessment of CSD satisfaction in the context of COVID-19 is a matter of concern in Vietnam. Since then, the Central bank of Vietnam and Vietnamese commercial banks have 
appropriate policies to serve CSD to meet consumers' needs. This contributed to the increase of credit mobilization for economic development to overcome difficulties during the COVID-19.

\section{Literature Review}

\subsection{Related Concepts}

\subsubsection{Satisfaction}

Satisfaction is seen in a number of different ways. According to Kotler and Keller (2011), satisfaction is the degree of human feeling from comparing one activity to another. Satisfaction level depends on what is expected compared to the actual results. Satisfaction is a person's feeling of desire, so the level of satisfaction depends on that feeling (Oliver, 1997). Hansemark and Albinsson (2004) argue that customer satisfaction reflects customer attitudes towards suppliers about what to expect with the actual results they receive. Although there are different views but overall, it is the satisfaction of the needs of customers from the suppliers of products and services.

\subsubsection{Customers' Savings Deposit (CSD)}

Savings is a popular form of investment today. It is rated as relatively safe and low risk. With this form, deposit money in the bank has the main purpose of generating savings (Far \& Zadeh, 2016). Savings deposit is also a form of bank deposits. Customers have many different reasons and needs when sending money to a bank. A certain amount of money is definitely used to save or invest, but is not suitable for personal spending and payment. The customer always wants to get a profit from savings deposit (Byusa, 2016).

\subsection{The Theory of Absolute and Permanent Income}

In economics, the absolute income hypothesis is mentioned by Keynes (1936) and is part of Keynesian consumption theory. According to this theory, consumers always consider to divide the income earned in the balance between consumption and savings. Meanwhile, the perpetual income assumption is that consumers always identify tangible, financial assets such as stocks, bonds, etc., or intangible assets such as knowledge and qualifications. These assets will affect consumers' ability to earn income. Consumers can estimate their expected income and that means their permanent income (Friedman, 1957). This theory is applied to explain factors related to satisfaction of CSD from sources of income, savings of the population, and deposit of individual customers.

\subsection{Previous Studies}

The research focuses on finding factors that discover CSD satisfaction. Byusa (2016) studied the factors affecting CSD satisfaction in African banks. The author used quantitative methods based on collecting survey data from five commercial banks in the period 2010-2014. The author focused on researching internal institutional factors including the policies of banks, branch development strategies, human resources, and external factors such as legal environment regulations, interest rate policies, competition, and people's income. The results show that both internal institutional and external factors have an impact on satisfaction. Far and Zadeh (2016) used OLS test to study the factors that affect the satisfaction of 384 CSDs in Iran banks. The results indicate that there are three positive influencing factors, including internal bank regulations, human resources, and infrastructure. Gunasekara and Kumari (2018) looked at the impact of factors on deposit mobilization. The authors used the OLS quantitative method with a sample of 120 customers in 2017. The research findings show a positive relationship between deposit mobilization and deposit interest rates, safety and security. The extent of branch expansion and services and information dissemination have a positive effect on the bank's deposit mobilization.

Maxwell et al. (2018) studied the satisfaction of 600 CSDs at 18 banks in Nigeria from 2012 to 2016 and used OLS to test. The results show that factors related to macroeconomic stability such as inflation and internal policies, and policies of the bank affect customer satisfaction. This shows the confidence and mind of CSD. Miklós et al. (2019) examined the impact of factors on customer satisfaction at Jordanian banks. The authors used a sample of 825 customers who were clients between 2017 and 2018. The authors used the OLS regression method. The results show that factors of human resources, infrastructure, products and services, and service quality affect customer satisfaction. Tabash et al. (2020) explored key aspects of the quality of e-Retail services of Islamic banks in the Kingdom of Saudi Arabia. The authors used a convenient sample size including 373 respondents. The authors used the E-Servqual scale. The results of the study show that reliability, responsiveness, ease-of-use, and security have created a significant impact on overall customer satisfaction.

In Vietnam, the number of studies on customer satisfaction is limited. Phan et al. (2015) used Serqual model to identify factors affecting satisfaction of customer with savings services at Agribank of Vinh Long province in 2014. The sample data includes 130 SCDs. The results show that factors affecting customer satisfaction include service quality, facilities, and human resource. Vuong et al. (2020) studied the main factors affecting individual customers' decision to deposit savings in Vietnamese commercial banks. The authors used 
survey data collected from 403 individual customers. The authors performed multiple regression analysis using SPSS software. Factors influencing individual customers' savings deposit decisions include promotions, bank brands, service quality, interest rate policies, and employee knowledge and attitudes. Although there is no study on the subject of deposit customers, the author also considered the satisfaction of digital banks in Vietnam (Nguyen, 2020). This author studied the factors affecting the intention to use digital banking in Vietnam. Multivariate data analysis technique with structural equation model was used to test. Survey data was collected from 201 customers accessing to digital banking. The results of the analysis show that employees' attitudes and useful awareness have a positive impact on the satisfaction of customers about digital banks, while trust and convenience do not affect the satisfaction in digital banking.

Mobilizing from CSD is necessary for the process of economic development so it has received some attention from previous researchers. Foreign studies are typically focused on a number of countries or regions, and there are no studies specific to Vietnam. The study of CSD satisfaction in Vietnam commercial banks has so far not benefited from in-depth research on this issue. Especially in the context of COVID-19, CSD's awareness has led to certain changes by regulations of state management agency, some policies of Vietnamese commercial banks as well as changing the form of promotion, products, and services to adapt to the general economic volatility.

\section{Research Design}

The paper uses the quantitative research method and the ordinary least square (OLS) method to regress the model scale factors affecting CSD satisfaction in Vietnamese commercial banks.

\subsection{Sampling Method}

The exploratory factor analysis (EFA) was used; Gorsuch (1983) suggested that the number of samples needed to ensure the reliability of the scale required five times or more the observed variables. Currently, Vietnam has 31 commercial banks; the authors send 2,000 surveys directly to CSDs of all commercial banks to ensure representation. The survey is random when CSDs come to make direct transactions at the bank. Some 1,639 CSD surveys were collected. Therefore, the survey samples are relevant. The survey was conducted at the end of the second quarter in 2020.

\subsection{The Scale}

The paper uses 7-point Likert scale - 1: Very Low; 2: Low; 3: Poor; 4: Medium; 4: Fair; 6: Good; and 7: Very
Good. The survey consists of 37 elements of eight variables in the model. The content of the survey relates to the variables inherited from previous studies and surveyed by some experts of Vietnamese commercial banks.

\subsection{Research Hypotheses}

\section{Legal provisions of the Central bank (LEGAL)}

The legal provisions of the banking system are those to create a unified and synchronized legal environment. These regulations will be designed by the state management agency through the administration of macroeconomic policies. These regulations will have a positive impact on CSD satisfaction and are reflected by Byusa (2016) and Maxwell et al. (2018). So, the article proposes the following hypothesis:

H1: Legal provision of the Central bank positively affects CSD satisfaction of Vietnamese commercial banks.

\section{Policies and regulations of bank (POLICY)}

The mechanism of banks is manifested through the development strategies of banking operations. It reflects compliance and consistency in regulations as well as compliance with policies and mechanisms. Procedures and processes are implemented flexibly in practice. These key policies and regulations ensure flexibility that will have a positive impact on CSD satisfaction and recognized by Byusa (2016); Far and Zadeh (2016) and Maxwell et al. (2018). Therefore, the following hypothesis is formulated:

H2: Policies and regulations of bank positively affect CSD satisfaction of Vietnamese commercial banks.

\section{Promoting the brand of bank (PROMOTE)}

The promotional activities help the bank provide information related to CSD satisfaction about the service packages being offered as well as incentives for customers to attract more capital to the commercial bank. This reflects the interest of banks in image building, branding and broad communication as well as the interest of customers in the brands of banks. Byusa (2016); Gunasekara and Kumari (2018); Vuong et al. (2020) and Nguyen (2020) suggest that the bank's brand promoting will increase the mobilization of capital. Therefore, the article hypothesizes that:

H3: Promoting the brand of bank has a positive impact on CSD satisfaction of Vietnamese commercial banks.

\section{Infrastructure of bank (INFRAS)}

The infrastructure provides customers with the convenience of dealing with the bank, from which the customer will gain sympathy that will increase the bank's 
capital. The infrastructure is shown through the expansion of branches, appropriate density distribution of branches, and advanced information technology in the application. This helps customers' convenience in the transaction. The majority of related studies (Phan et al., 2015; Far \& Zadeh, 2016; Gunasekara \& Kumari, 2018; Miklós et al., 2019; Tabash et al., 2020; Vuong et al., 2020; Nguyen, 2020) recognize this factor has a positive impact on CSD satisfaction. Consistent with the views of the previous authors, the proposed hypothesis is:

H4: Infrastructure of bank affects in the same direction to CSD satisfaction of Vietnamese commercial banks.

\section{Human resources of bank (HUMAN)}

Bank staff is the intermediary that communicates between the bank and its customers. To meet the needs of customers and provide good service quality, the bank needs to employ qualified and skilled staff. This is reflected through the policy of attracting quality human resources as well as training and retraining to meet the increasing demands of customers. Some previous studies by Phan et al. (2015); Byusa (2016); Far and Zadeh (2016); Miklós et al. (2019) and Vuong et al. (2020) believe that the quality of human resources of the bank has a positive effect on CSD satisfaction. On that basis, the following hypothesis is proposed:

H5: Human resources of bank influence on CSD satisfaction of Vietnamese commercial banks.

\section{Service quality of bank (SERVICE)}

Good service quality helps to satisfy and satisfy customers' needs. This is an important tool for banks to attract capital. It shows enthusiasm and customer care in a considerate and friendly way through dedicated, thoughtful and clear guidance as well as timely resolution of customer problems and difficulties. A number of previous studies by Phan et al. (2015); Gunasekara and Kumari (2018); Miklós et al. (2019); Vuong et al. (2020) and Nguyen (2020) stated that the better the quality of customer service, the higher the CSD satisfaction. Therefore, the following hypothesis is:

H6: Service quality of bank positively affects CSD satisfaction of Vietnamese commercial banks.

\section{Products of bank (PRODUCT)}

More diverse products and services of the bank, in accordance with the needs of customers, will be favorable in attracting capital. The bank's products are represented by preferential interest packages, after-sales policies, bonuses, and flexibility in the provision of interest. These are important and positive factors for banks in attracting capital. Previous authors such as Byusa (2016); Gunasekara and Kumari (2018); Miklóset al. (2019) and Vuong et al. (2020) agree that the bank's products and services contribute to CSD satisfaction. Therefore, the following hypothesis is proposed:

H7: Products of bank influence positively on CSD satisfaction of Vietnamese commercial banks.

Table 1: Summary of variables, expectation signs and related previous studies

\begin{tabular}{|l|l|c|l|}
\hline $\begin{array}{l}\text { Name of } \\
\text { variables }\end{array}$ & Description of variables & $\begin{array}{c}\text { Expectation } \\
\text { signs }\end{array}$ & \\
\hline Dependent variable & & \\
\hline SATIS & Satisfaction of CSD & & Previous studies \\
\hline Independent variables & & + & Byusa (2016) and Maxwell et al. (2018) \\
\hline LEGAL & $\begin{array}{l}\text { Legal provisions of the } \\
\text { Central bank }\end{array}$ & + & Byusa (2016); Far \& Zadeh (2016) and Maxwell et al. (2018) \\
\hline POLICY & $\begin{array}{l}\text { Policies and mechanisms } \\
\text { of bank }\end{array}$ & + & $\begin{array}{l}\text { Byusa (2016); Gunasekara \& Kumari (2018); Vuong et al. (2020) } \\
\text { and Nguyen (2020) }\end{array}$ \\
\hline PROMOTE & $\begin{array}{l}\text { Promoting the brand of } \\
\text { bank }\end{array}$ & + & $\begin{array}{l}\text { Phan et al. (2015); Far \& Zadeh (2016); Gunasekara \& Kumari } \\
\text { (2018); Miklós et al. (2019); Tabash et al. (2020); Vuong et al. } \\
\text { (2020) and Nguyen (2020) }\end{array}$ \\
\hline HNFRAS & Infrastructure of bank & + & $\begin{array}{l}\text { Phan et al. (2015); Byusa (2016); Far \& Zadeh (2016); Miklós et } \\
\text { al. (2019) and Vuong et al. (2020) }\end{array}$ \\
\hline SERVICE & Service quality of bank & $\begin{array}{l}\text { Phan et al. (2015); Gunasekara \& Kumari (2018); Miklós et al. } \\
\text { (2019); Vuong et al. (2020) and Nguyen (2020) }\end{array}$ \\
\hline PRODUCT & Products of bank & $\begin{array}{l}\text { Byusa (2016); Gunasekara \& Kumari (2018); Miklós et al. (2019) } \\
\text { and Vuong et al. (2020) }\end{array}$ \\
\hline
\end{tabular}




\subsection{Research Model}

The study follows the model of CSD satisfaction assessment by Parasuraman et al. (1988) and Parasuraman et al. (1991). This model is popular due to its simplicity and adaptability under common conditions. In addition, the article inherits the independent variables from previous research, combined with consultation with experts in Vietnamese commercial banks. Therefore, the article proposes a research model on the factors affecting CSD satisfaction in Vietnamese commercial banks (see Table 1), specifically:

\section{SATIS $=\beta 0+\beta 1 *$ LEGAL $+\beta 2 *$ POLICY $+\beta 3 *$ PROMOTE $+\beta 4 *$ INFRAS $+\beta 5^{*}$ HUMAN $+\beta 6^{*}$ SERVICE $+\beta 7 *$ PRODUCT $+\varepsilon$}

\section{Research Results}

To assess the factors affecting CSD satisfaction of Vietnamese commercial banks, the article performs some tests, specifically:

\section{Table 3. Rotation matrix}

\begin{tabular}{|c|c|c|c|c|c|c|c|}
\hline \multirow{2}{*}{ Variables } & \multicolumn{7}{|c|}{ Component } \\
\hline & 1 & 2 & 3 & 4 & 5 & 6 & 7 \\
\hline INFRAS 3 & .842 & & & & & & \\
\hline INFRAS 5 & .782 & & & & & & \\
\hline \begin{tabular}{|l} 
INFRAS 4 \\
\end{tabular} & .763 & & & & & & \\
\hline INFRAS 2 & .742 & & & & & & \\
\hline INFRAS 1 & .681 & & & & & & \\
\hline INFRAS 6 & .642 & & & & & & \\
\hline \begin{tabular}{|l|} 
HUMAN 3 \\
\end{tabular} & & .642 & & & & & \\
\hline HUMAN 1 & & .602 & & & & & \\
\hline HUMAN 2 & & .571 & & & & & \\
\hline HUMAN 4 & & .686 & & & & & \\
\hline HUMAN 5 & & .593 & & & & & \\
\hline SERVICE 3 & & & .714 & & & & \\
\hline SERVICE 4 & & & .741 & & & & \\
\hline SERVICE 2 & & & .683 & & & & \\
\hline SERVICE 1 & & & .587 & & & & \\
\hline PRODUCT 2 & & & & .708 & & & \\
\hline PRODUCT 5 & & & & .724 & & & \\
\hline PRODUCT 4 & & & & .714 & & & \\
\hline PRODUCT 3 & & & & .646 & & & \\
\hline PRODUCT 1 & & & & .673 & & & \\
\hline \begin{tabular}{|l|} 
LEGAL 4 \\
\end{tabular} & & & & & .742 & & \\
\hline $\begin{array}{l}\text { LEGAL } 5 \\
\end{array}$ & & & & & .714 & & \\
\hline \begin{tabular}{|l|} 
LEGAL 2 \\
\end{tabular} & & & & & .818 & & \\
\hline LEGAL 3 & & & & & .723 & & \\
\hline $\begin{array}{l}\text { LEGAL } 1 \\
\end{array}$ & & & & & .762 & & \\
\hline PROMOTE 3 & & & & & & .681 & \\
\hline PROMOTE 2 & & & & & & .742 & \\
\hline PROMOTE 1 & & & & & & .637 & \\
\hline POLICY 1 & & & & & & & .717 \\
\hline POLICY 2 & & & & & & & .652 \\
\hline POLICY 3 & & & & & & & .648 \\
\hline POLICY 4 & & & & & & & .639 \\
\hline
\end{tabular}

\subsection{Bartlett and KMO Test}

Kaiser (1974) suggested that to carry out EFA, KMO condition ought to be greater than 0.50 and if greater than 0.90 , it is very significant in testing. According to the results of Table 2, KMO is 0.912 , greater than 0.90 , so it satisfies the conditions to implement EFA. Bartlett's sig is 0.000 (less than $0.5 \%$ ), so the data set is perfectly appropriate. Moreover, the significance level of the result is 0.00 (less than 0.05), so it is statistically significant. With this result, the data are suitable for EFA implementation.

Table 2: Bartlett and KMO tests

\begin{tabular}{|l|l|c|}
\hline \multicolumn{2}{|l|}{$\begin{array}{l}\text { Kaiser-Meyer-Olkin Measure of Sampling } \\
\text { Adequacy }\end{array}$} & .912 \\
\hline $\begin{array}{l}\text { Bartlett's Test of } \\
\text { Sphericity }\end{array}$ & Approx. Chi-Square & 5864,800 \\
\hline & Df & 482 \\
\hline & Sig. & .000 \\
\hline
\end{tabular}


Table 4: Reliability

\begin{tabular}{|l|c|c|}
\hline Variables & Cronbach's alpha & N of Items \\
\hline SATIS & .889 & 5 \\
\hline LEGAL & .912 & 5 \\
\hline POLICY & .906 & 4 \\
\hline PROMOTE & .911 & 3 \\
\hline HUMAN & .924 & 5 \\
\hline INFRAS & .918 & 6 \\
\hline SERVICE & .903 & 4 \\
\hline PRODUCT & .918 & 5 \\
\hline
\end{tabular}

Table 5: Model Summary

\begin{tabular}{|l|c|c|c|}
\hline Model & $\mathbf{R}$ & R Square & $\begin{array}{c}\text { Adjusted } \\
\text { R Square }\end{array}$ \\
\hline 1 & .812 & .764 & .712 \\
\hline
\end{tabular}

\subsection{Analysis of Exploratory Factors}

Hair et al. (2009) suggested that load factor is the norm to ensure the practical significance level of EFA with the minimum condition of greater than 0.30 and, if greater than 0.50 , it is considered as having more meaning. With the results of Table 3, most factor load factors are greater than 0.50 , so this data set is meaningful. In addition, the result has seven columns, which means that there are seven factors drawn from 32 observation factors related to the independent variables. Since, the adaptive research model corresponds to the proposed model presented above.

\subsection{Test the Reliability of Scales}

Nunnally and Burnstein (1994) argued that to ensure the reliability of the scale, Cronbach's alpha must reach 0.60 . The results of Table 4 shown that all variables have a coefficient greater than 0.60 , so the data ensures the reliability of the information.

\subsection{Assess the Suitability of the Model}

Horn and Johnson (1994) considered the higher R square to be the basis of the stronger correlation between the independent and dependent variables. Table 5 shows that the adjusted $\mathrm{R}$ square is equal to 0.721 . This means the independent variable explains $72.1 \%$ of the variation of the dependent variable. Overall the interpretation of the model is quite good.

\subsection{Regression Results}

Variables are selected in the model when the significance level is less than 0.05 . The results have three significant variables. With the results of Table 6 , the regression result is as follows:

$$
\begin{aligned}
\text { SATIS }= & 0.412 * \text { LEGAL }+0.128 * \text { POLICY } \\
& +0.124 * \text { PRODUCT }
\end{aligned}
$$

To consider multicollinearity, as shown in Table 6 on the correlation coefficient matrix, the results show that the magnification coefficient of variance (VIF) is low. It shows that the model has no collinearity phenomenon.

\subsection{Discussion}

The results of this study are similar to those of previous studies related to the factors affecting CSD satisfaction of banks such as Byusa (2016); Maxwell et al. (2018); Gunasekara and Kumari (2018); Miklós et al. (2019). However, these research results are different from some previous studies on Vietnam, such as Phan et al. (2015); Vuong et al. (2020) and Nguyen (2020). This explains that, under different economic conditions and circumstances, CSD satisfaction will change. This is also consistent with the opinion of experts in Vietnamese commercial banks that there will be changes in the factors affecting CSD satisfaction due to certain economic difficulties of CSD.

The results show that there are three factors that positively affect CSD satisfaction during the context of COVID-19, of which the most influential variable is the banking system of regulations, policies and mechanisms, followed by translated products of Vietnamese commercial banks. This result has been explained in relation to the basic theory of the income of deposit customers. Customers are always in a balance between consumption and savings, especially economic difficulties in the future vision of COVID-19.

The coefficient of the variable on legal provisions of the Central bank (Legal) is equal to 0.412, greater than zero. This shows the relationship with the variable with the dependent variable (SATIS). This implies that, when the legal environment of Central bank of Vietnam ensures stability and consistency, the corresponding tendency will attract CSD, and vice versa. This result is similar to some previous studies related to Byusa (2016) and Maxwell et al. (2018).

Similar to the legal variable, the coefficient of the policies and mechanisms of bank (Policy) variable is equal to 0.128 , greater than zero. This also shows the relationship of the same variable with the dependent variable (SATIS). This implies that, when the preferential policies and flexible mechanisms of commercial banks increase, it correspondingly attracts CSD, and vice versa. This result is similar to some related studies by Byusa (2016); Gunasekara \& Kumari (2018). 
Table 6. Coefficients

\begin{tabular}{|c|c|c|c|c|c|c|c|c|}
\hline \multicolumn{2}{|c|}{ Model } & \multicolumn{2}{|c|}{$\begin{array}{l}\text { Unstandardized } \\
\text { Coefficients }\end{array}$} & \multirow{2}{*}{$\begin{array}{c}\begin{array}{c}\text { Standardized } \\
\text { Coefficients }\end{array} \\
\text { Beta }\end{array}$} & \multirow[t]{2}{*}{$\mathbf{T}$} & \multirow{2}{*}{ Sig. } & \multicolumn{2}{|c|}{ Collinearity Statistics } \\
\hline & & B & Std. Error & & & & Tolerance & VIF \\
\hline \multirow[t]{8}{*}{1} & (Constant) & .418 & .210 & & 2.841 & .000 & & \\
\hline & LEGAL & .463 & .036 & .412 & 4.716 & .000 & .587 & 1.912 \\
\hline & POLICY & .168 & .051 & .128 & 2.432 & .000 & .562 & 1.942 \\
\hline & PROMOTE & .238 & .025 & .192 & 3.048 & .608 & .394 & 2.714 \\
\hline & HUMAN & .123 & .054 & .109 & 2.318 & .711 & .328 & 3.318 \\
\hline & INFRAS & .254 & .064 & .194 & 3.612 & .109 & .394 & 2.549 \\
\hline & SERVICE & .127 & .061 & .113 & 2.461 & .235 & .356 & 2.317 \\
\hline & PRODUCT & .132 & .047 & .124 & 2.241 & .000 & .316 & 2.372 \\
\hline
\end{tabular}

Like the two variables above, the coefficient of the products of bank (Product) variable equal to 0.124 is greater than zero. This shows the relationship of the same variable with the dependent variable (SATIS). This means that when commercial banks have more diverse products with each increased product package, it correspondingly attracts CSD, and vice versa. This result is similar to some related studies by Byusa (2016); Gunasekara and Kumari (2018); Miklós et al. (2019) and Vuong et al. (2020).

\section{Conclusion and Policy Recommendations}

\subsection{Conclusion}

In the trend of integration and development, mobilizing capital sources for economic development, in which CSD plays a big role, is important to attract economic resources. The article conducted a survey with 1,639 CSD of Vietnamese commercial banks at the end of the second quarter in 2020. The results show that there are three variables that positively affect CSD satisfaction - legal provisions of the Central bank (Legal), policies and mechanisms of bank (Policy), and products of bank (Product). Accordingly, in order to contribute to strengthening CSD satisfaction, the Central bank of Vietnam needs to play a leading and pivotal role in the regulations of the banking system; propagates regulations to make customers feel secure and have confidence in sending money; and provides timely financial support packages. It is a useful solution to stabilize the financial resources of the banking system. Meanwhile, Vietnamese commercial banks need flexible policies and mechanisms to stimulate CSD; strengthen support on deposit rates for CSD; and encourage the development of product diversification to facilitate adapting to each situation of CSD. This helps to maximize the financial resources of commercial banks from CSD.

\subsection{Policy Recommendations}

Some policy suggestions based on the results of the model ought to contribute to the Central bank of Vietnam and Vietnamese commercial banks in the implementation of policies and management of the banking system. This supports the banking system to overcome certain obstacles and difficulties caused by the COVID-19, which may continue in the near future. It will cause stagnation and slow economic growth of the banking system.

The Central bank of Vietnam needs to play a key and pivotal role in the regulation of the banking system. Central banks need to maintain the stability of the banking system's regulations to enhance the confidence of deposit customers. In recent economic fluctuations, Central banks need communication to explain in order to avoid causing people's confusion, especially rural people in the provinces. Moreover, the Central bank needs to control monetary policy, interest rates, and inflation to keep a stable position in the economy. In addition, it needs to provide financial support packages from the government fund for Vietnamese commercial banks. This helps commercial banks to implement timely policies in business activities. It is a useful solution for commercial banks to stabilize financial resources.

Vietnamese commercial banks need flexible policies and mechanisms to stimulate CSD. Commercial banks need to increase the support to mobilize interest rates for CSD. For products and services, commercial banks need to encourage product development for loyal customers, or family savings. This means involving family members in savings to stimulate increased participation resources. In addition to the various forms of mobilization in terms of time, deposit value, interest rate incentives or bonuses, gifts continue to maintain and promote CSD. In the context of common difficulties, the diversification of products of commercial banks will be easily adapted to each CSD's situation. This helps to maximize the financial resources from CSD. 


\section{References}

Byusa, M. (2016). Factors Influencing Savings Mobilization by Commercial Banks. PhD thesis, Strathmore University, Rwanda. https://su-plus.strathmore.edu/bitstream/handle/11071/4763/ Byusa\%20Marcel.pdf? sequence $=2$.

Central Bank of Vietnam. (2020). Regulations on Re-Financing of Capital for Social Policy Bank under the Prime Minister's Decision No. 15/2020 / QD-TTg of April 24, 2020. Vietnam News. Retrieved July 16, 2020, from https://thuvienphapluat. vn/van-ban/tien-te-ngan-hang/Circular-05-2020-TT-NHNNrefinancing-loans-granted-under-Decision-15-2020-QDTTG-442801.aspx.

Far, A. A., \& Zadeh, R. L. (2016). Factors Affecting the Success of Iranian banks in mobilizing financial resources (Case study of Maskan bank in Isfahan Province). International Journal of Humanities and Cultural Studies, 1626 -1635.

Gorsuch, R. L. (1983). Factor analysis (2 ${ }^{\text {nd }}$ ed.). Hillsdale, MI: L. Erlbaum Associates.

Gunasekara, H. U., \& Kumari, P. (2018). Factors Affecting for Deposit Mobilization in Sri Lanka. International Review of Management and Marketing, 8(5), 30-42.

Hair, J. F., Black, W. C., Babin, B. J. \& Andersom, R. E. (2009). Multivariate Data Analysis. Upper Saddle River, NJ: PrenticeHall International, Inc.

Hansemark, O. C., \& Albinson, M. (2004). Customer Satisfaction and Retention: The Experiences of Individual Employees. Managing Service Quality: An International Journal, 14(1), 40-57.

Horn, R. A., \& Johnson, C. R. (1994). Matrix Analysis. Cambridge University Press.

Kaiser, H. F. (1974). An index of factorial simplicity. Psychometrika, 39(1), 31-36.

Keynes, J. M. (1936). The General Theory of Employment, Interest and Money. London, UK: Macmillan.

Kotler, P., \& Keller, K. L. (2011). Marketing Management. London, UK: Pearson Education.
Friedman, M. (1957). A Theory of the Consumption Function. Princeton, NJ: Princeton University Press.

Maxwell, W. P., Julius, A. A., \& Mariam, W. T. (2018). Efficiency, customers' satisfaction and deposit money banks' performance in Nigeria. Journal of Economics and Management, 31(1), 133-148.

Miklós, P., Haddad, H. B., Nagy, J., \& Popp, J. (2019). The Service Quality Dimensions that Affect Customer Satisfaction in the Jordanian Banking Sector. Sustainability, 11, 1113. DOI: 10.3390/su11041113.

Nguyen, T. O. (2020). Factors Affecting the Intention to Use Digital Banking in Vietnam. Journal of Asian Finance, Economics and Business, 7(3), 303-310. doi:10.13106/jafeb.2020.vol7.no3.303

Nunnally, J. C., \& Burnstein, I. H. (1994). Psychometric Theory. New York, NY: McGraw-Hill.

Oliver, R. L. (1997). Satisfaction: A Behavioural Perspective on the Consumer. New York, NY: McGraw Hill.

Parasuraman, A., Zeithaml, V. A., \& Berry, L. L. (1988). Servqual: A Multiple-Item Scale for Measuring Consumer Perceptions of Service Quality. Journal of Retailing, 64(1), 12-40.

Parasuraman, A., Berry, L. L., \& Zeithaml, V. A. (1991). Refinement and Reassessment of the Servqual Scale. Journal of Retailing, 67(4), 420-450.

Phan, D. K., Thai, V. D., Hoang, T. H., \& Nguyen, Q. T. (2015). Factors affecting customer satisfaction level of savings deposit services: The case of Agribank Binh Minh of Vinh Long province, Vietnam. Journal of Science, 40(2015), 50-57.

Tabash, M. I, Albugami, M. A., Salim, M., \& Akhtar, A. (2019). Service Quality Dimensions of E-retailing of Islamic Banks and Its Impact on Customer Satisfaction: An Empirical Investigation of Kingdom of Saudi Arabia. Journal of Asian Finance, Economics and Business, 6(3), 225-234. https://doi. org/10.13106/jafeb.2019.vol6.no3.225.

Vuong, B. N, Tung, D. D, Giao, H. N. K, Dat, N. T., \& Quan, T. N. (2020). Factors Affecting Savings Deposit Decision of Individual Customers: Empirical Evidence from Vietnamese Commercial Banks. Journal of Asian Finance, Economics and Business, 7(7), 293-302. https://doi.org/10.13106/jafeb.2020.vol7.no7.293. 